and talking about energy." Many gubernatorial candidates, including Wisconsin's Doyle and Ted Kulongoski, Democratic governor of Oregon, are advancing some version of the ' 25 by 25 ' pledge - the broad-based push to produce $25 \%$ of the country's energy from renewable sources by 2025 .

The issue has come into play in closely fought Senate races as well - and again on both sides of the partisan divide. In Washington state, Democratic senator Maria Cantwell is posing with wind turbines even as her Republican opponent proclaims his support for heavy investment in alternative energy. In Tennessee, Democratic candidate Harold Ford runs adverts wherein he strides across fields of soya beans grown for biofuel. In New Jersey, Republican challenger Tom Kean says that, "unlike President Bush", he doesn't think America can "drill its way to energy independence".

The interest in energy issues runs deep. Earlier this year, the liberal citizens' group MoveOn.org staged more than 1,000 house parties, asking attendees to name the issues they thought the group should press hard on for the elections. "There were just two issues that came up at every one of those house parties," says Eli Pariser, executive director of MoveOn's political action committee. "One was health care and one was energy." For Pariser, the issue is about more than oil prices and geopolitics: ${ }^{\alpha}$ There is this sense of a grand scientific exploration in the style of the campaign to put a man on the Moon. People are
The push towards using clean energy sources, such as biofuel derived from crops, has been used by some candidates to woo floating voters.
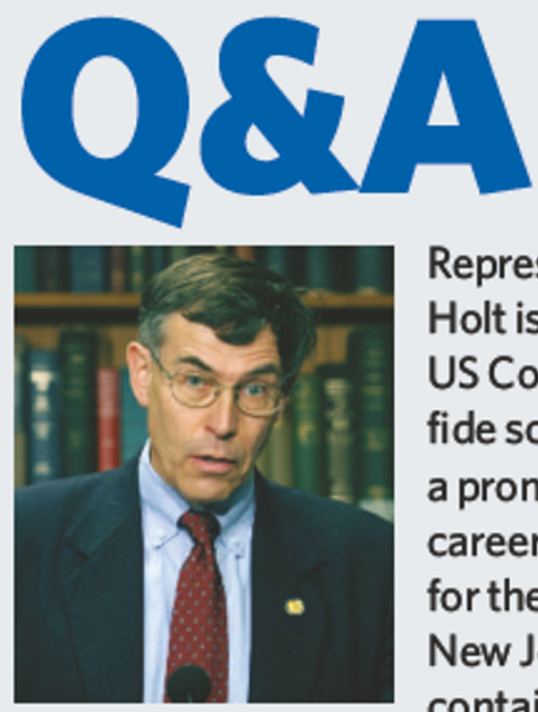

\section{Representative Rush} Holt is a rare thing in the US Congress - abona fide scientist building a promising political career. Since his election for the 12th district of New Jersey - the one containing Princeton -

eight years ago, this former physicist and son of a West Virginia senator has garnered several powerful committee slots. Holt has emerged as one of the Democratic Party's most prominent spokesmen on science, education and security. Colin Macilwain asked him about the life of a scientist on Capitol Hill, and what the mid-term elections could mean for science and education.

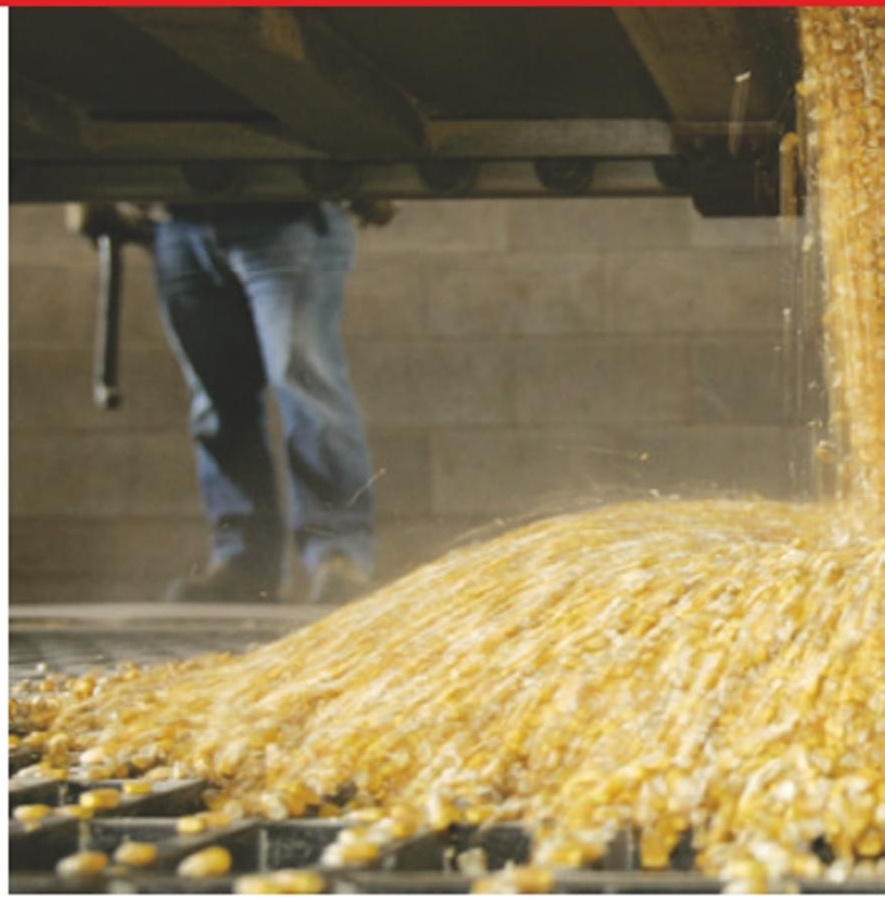

hungry right now to be asked to be part of a big project. But some routes towards energy independence involve extracting non-renewable energy sources - such as drilling in the Arctic National Wildlife Refuge, a plan pushed heavily by Ted Stevens, a Republican senator from Alaska. The drive for energy independence shouldn't edipse the message of preparing for dimate change, argues Alden Meyer, director of strategy and policy for the Union of Concerned
What difference would it make to science, or to scientists in America, if the Democrats took control of the House of Representatives?

The atmosphere in Washington is more politically partisan than I have seen in half a century, and it even affects things like science. I've never believed that science is completely removed from policy or politics. But many scientists would say they are appalled at the way a political game has been made of science, such as intelligent design in the schools, where both the president and some in Congress have said that both this and evolution should be taught. And climate change - until very recently it's been difficult to get anyone to acknowledge that there is climate change and that there is any connection with human activity.

Are scientific issues arising as issues in campaigns around the country?

Not as major issues, but in my district there is a kind of frustration that we've been unable to deal with energy problems
- it might be high fuel prices, but somewhere in the voters' minds it is connected with a failure to find alternatives to fossil fuels, and a failure to listen to scientific analysis on climate change and that sort of thing.

\section{Do the Democrats have a} programme for science, technology and education and, if so, what is it? It may not be as well known or as well understood as we would wish. We do have a good message ['The Innovation Agenda'] released six or eight months ago. It calls for nationwide broadband, a greater investment in research and greatly increasing the number of trained science teachers in the schools.

But isn't it true that, historically, Republicans are likely to spend more money on research and development?

The president has acknowledged that the physical sciences have languished, but in the latest budget, not much has come through. So I'm not willing to elevate him to the hall of fame. 
